Article

\title{
Bioconnections as Enablers of Regenerative Circularity for the Built Environment
}

\author{
Henrique Sala Benites * and Paul Osmond \\ School of Built Environment, University of New South Wales, Australia; E-Mails: h.salabenites@unsw.edu.au (H.S.B.), \\ hsbenites@gmail.com (H.S.B.), p.osmond@unsw.edu.au (P.O.) \\ * Corresponding author
}

Submitted: 15 April 2021 | Accepted: 18 June 2021 | Published: 14 October 2021

\begin{abstract}
Learning from nature may be the most important step towards improving cities in the context of environmental and climate issues. However, many of the current approaches to make cities greener or more sustainable are still linear and insufficient to deal with these growing challenges. In this scenario, the adoption of regenerative and circular lenses for the built environment may foster a more holistic development based on what is good rather than what is less bad. In this article, we propose that bioconnectivity or bioconnections-a nature-focused approach based on biophilic design, biomimetics, and ecosystem services-may be an important enabler for the regeneration of the ecological and social boundaries of the planetary boundaries and doughnut economics models. We examine the literature to identify in what ways bioconnections could facilitate circular and regenerative processes for the local scale of the built environment domain. We complement the discussion with some real-world examples from selected urban communities or interventions in existing urban areas around the globe that claim a green approach. In the end, we propose a framework of relevant bioconnections for the built environment that could facilitate addressing ecological and social boundaries at the local urban scale and facilitate processes of regenerative transitions towards thriving communities.
\end{abstract}

\section{Keywords}

circular economy; circularity; nature-based solutions; regenerative design and development; urban bioeconomy; urban green infrastructure; urban sustainability

Issue

This article is part of the issue "Towards Green(er) Cities: Contextualizing Green Benefits for Urban Spaces and Contemporary Societies" edited by Juaneé Cilliers (University of Technology Sydney, Australia).

(C) 2021 by the authors; licensee Cogitatio (Lisbon, Portugal). This article is licensed under a Creative Commons Attribution 4.0 International License (CC BY).

\section{Introduction}

Humanity faces a diverse set of global challenges. The consequences of unfettered development have been the overshooting of key planetary ecological boundaries (Rockström et al., 2009). The global annual extraction of resources has increased from 27 billion tons to 92 billion tons in 47 years (IRP, 2019), with only $8.6 \%$ of the resources cycling back into the economy (Circle Economy, 2021), and $50 \%$ of the use happening because of cities (IRP, 2018). In response, an increasing number of buildings and communities have claimed to be green, ecolog- ical, or sustainable-many still based on a fragmented and linear approach.

Therefore, we need disruptive changes to reverse the trend and start directing systems towards a regenerative and circular economy and society.

"Regenerative design," proposed by John Lyle, has strong roots in metabolic and "systems thinking" of selfrenewing flows and stocks, to "replace the present linear system of throughput flows with cyclical flows" (Lyle, 1994, p. 10), which evolved into a more holistic approach with a vision of humankind integrated and co-evolving with nature to achieve positive impact (Reed, 2007). 
The idea of circular systems, which Birkeland (2019) categorises into hard/technocratic, soft/social, and living/organic systems, had been proposed a few decades earlier in the wake of the space race through the idea of Earth as a spaceship (Fuller, 1969), an enclosed cyclical ecological system (Boulding, 1966/2011). This later developed into circular economy through the works of many authors as Stahel (1982), Pearce and Turner (1989), and, more recently, the Ellen Macarthur Foundation (2013). There is, however, strong criticism that circular economy's technocratic emphasis does little to reduce the capitalist and materialistic approach to resources and reduced focus on social aspects (Calisto Friant et al., 2020).

One way of addressing this issue is the "doughnut economics" (DE) model (Raworth, 2017). The doughnut is composed of two concentric circles that represent the ecological and social boundaries, i.e., the limits of different global systems we must not overshoot to maintain humanity's wellbeing. The inner circle represents the social boundaries or social foundation, as access to food, health, education, social equity, among others, below which society would be falling short of their life's essentials. The outer circle, or the ecological ceiling, incorporates the "planetary boundaries" (PB) framework, which defines the safe operating space within which Earth's biophysical systems and processes (e.g., climate change, freshwater, biodiversity, among others) should operate (Rockström et al., 2009; Steffen et al., 2015). Although not specifically designed to be downscaled to the local scale, applying PB thinking at the local level is desirable (Steffen et al., 2015). As such, both PB (Figure 1a) and DE (Figure $1 b$ ) have been represented at the national (Lucas \& Wilting, 2018; O'Neill et al., 2018) and city (Hoornweg et al., 2016; Norman \& Steffen, 2018) levels.
Desing et al. (2020) proposed circular economy as a pathway for companies to improve resource use based on PB limitations, and Amsterdam was the first city to include $D E$ into its guide for a circular and regenerative city (DEAL et al., 2020).

As we approach the sixth major extinction event with increasing loss of biodiversity, including biodiversity impacts of climate change (Chapin et al., 2000) and resource use (IRP, 2019), it is of particular importance to understand how the built environment of cities can contribute to regenerating ecosystems. Circular economy studies usually emphasize the benefits of technical solutions and ignore how potential increases in production under a consumerist mindset could lead to more impacts on the biosphere (Buchmann-Duck \& Beazley, 2020). A nature-based focus, however, can be an important enabler of ecological and social boundaries.

Thus, as circular economy is increasingly advocated by governments (European Commission, 2019, 2020) and businesses (Ellen MacArthur Foundation, 2020), circular practices should evolve from their focus on resources to positively contribute to the biosphere and society through a more systemic approach, a "regenerative circularity" to reverse the impacts from the flows of resources into cities without ignoring social aspects. The incorporation of "nature-based solutions" the "actions to protect, sustainably manage, and restore natural or modified ecosystems, that address societal challenges effectively and adaptively, simultaneously providing human well-being and biodiversity benefits" (International Union for Conservation of Nature, 2016) - into regenerative and circular design for the built environment has been increasingly explored. Pedersen Zari looked into "ecosystem services"-the benefits
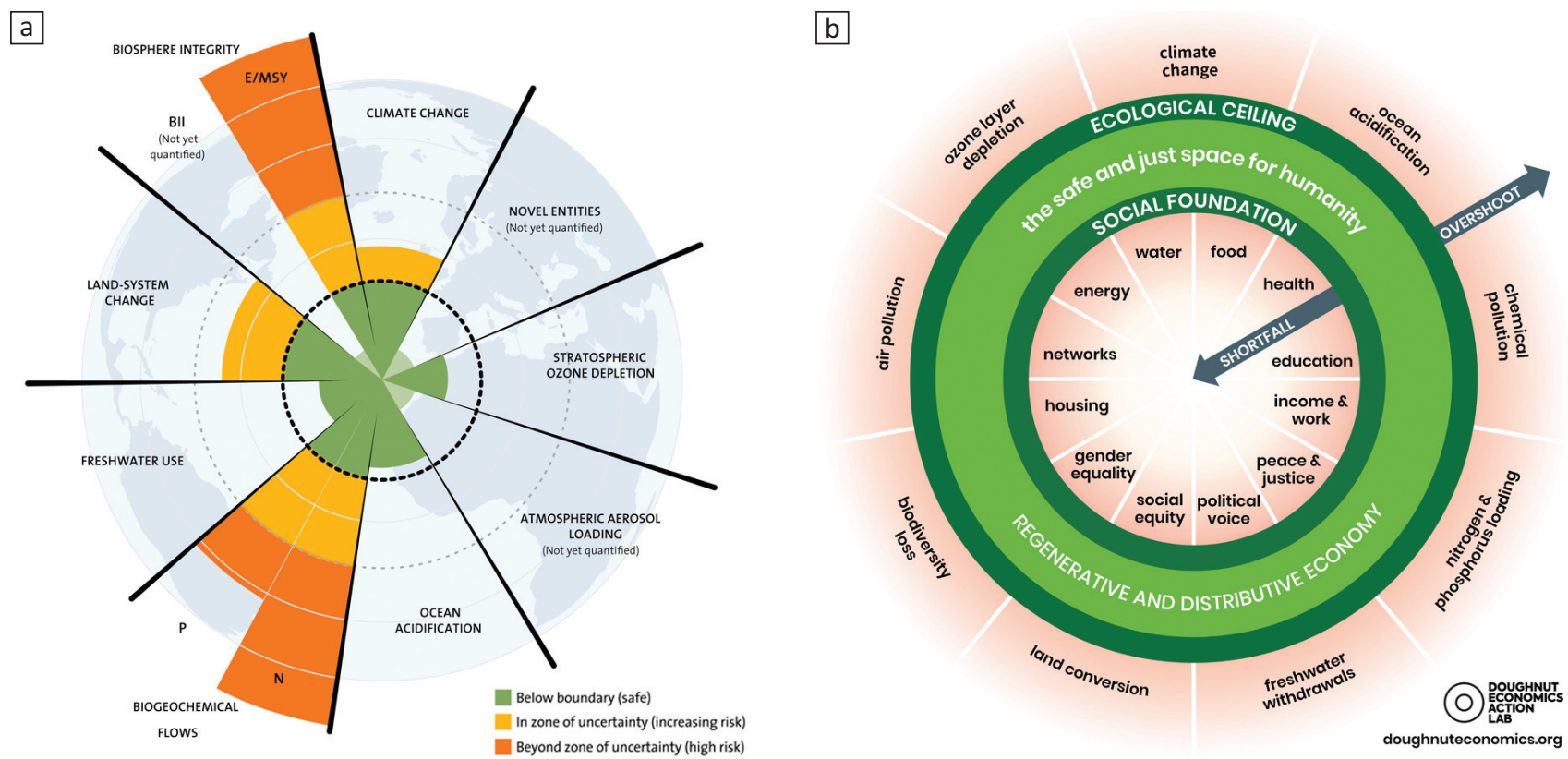

Figure 1. (a) PB framework, and (b) the "doughnut" of social and PB. Sources: (a) J. Lokrantz/Azote, based on Steffen et al. (2015); (b) Kate Raworth and Christian Guthier (CC-BY-SA 4.0; Raworth, 2017). 
from nature to humankind (Millennium Ecosystem Assessment, 2005)-for regenerative urban design (Pedersen Zari, 2015) leaving cultural ecosystem services aside and examined energy and water provision (Pedersen Zari, 2017a) and materials selection (Pedersen Zari, 2017b), but without direct linkages to PB or DE.

Building on those precedents, this article proposes adopting a "nature" perspective (Figure 2), which here we call "bioconnectivity" or "bioconnections," to improve circular and regenerative practices in the built environment as a way of addressing the ecological and social boundaries of the DE model. First, we look into different concepts to define the idea of bioconnections, then, for selected ecological and social boundaries, we examine the literature to map in what ways bioconnections could facilitate circular and regenerative processes for the local scale. We complement the discussion with some examples from selected urban communities or interventions in existing urban areas around the globe that claim a green approach. Finally, we propose a framework of relevant bioconnections for each ecological and social boundary.

\section{Bioconnections for a Regenerative and Circular Built Environment}

There are different ways in which bioconnectivity or bioconnections-i.e., the solutions, initiatives, interventions, or strategies that promote the reconnection between humans and nature, ensuring adequate stewardship, maintenance, and regeneration of biodiversity, enabling the provision of ecosystem services sustainably into the future-could be encouraged in urban environments. Benyus (2015) suggests the cities of the future should be generous, i.e., inspired by how a forest works and function as giant organisms, which treat their water, sequester carbon, clean the air, produce food and energy, among other functions. This reflects her previous work on "biomimicry," the development of technical solutions based on natural mechanisms (Vincent et al., 2006). More than inspiring solutions, bioconnections encompass the ideas of "biophilia," "the innately emotional affiliation of human beings to other living organisms" (Kellert \& Wilson, 1993, Chapter 1, para. 1), nature-based solutions, and ecosystem services. These different approaches, when in tandem, may support the evolutionary transition from degenerative to regenerative proposed by Mang and Reed (2012).

Bioconnected solutions are progressively becoming reality in urban planning and architecture through "green infrastructure" interventions. Green infrastructure refers to "the network of natural and semi-natural areas... which together enhance ecosystem health and resilience, contribute to biodiversity and benefit human populations through the maintenance and enhancement of ecosystem services" (Naumann et al., 2011, p. 14). Working with bioconnectivity in cities requires acknowledging the unique features of urban biodiversity that derive from anthropogenic alterations (Ellis \& Ramankutty, 2008), and the need for novel adaptive ecosystems for a changing climate (Oke et al., 2021), which may not allow restoring urban areas to their previous condition (Murphy, 2015).

In the following sections we seek to identify and explore in what ways bioconnections may enable a regenerative and circular approach to ecological and social boundaries in the built environment. We reinterpret selected ecological and social boundaries for a built environment context and consider their links with ecosystem services (Pedersen Zari, 2012).

\subsection{Climate Change}

Biobased climate change mitigation is an important ecosystem service. Apart from local greenhouse gas emissions from fossil-fuel energy and waste (Norman \& Steffen, 2018), cities rely heavily on high-emitting industries outside their borders, such as agriculture and forestry, resource extraction, and energy generation (Hoornweg et al., 2011).

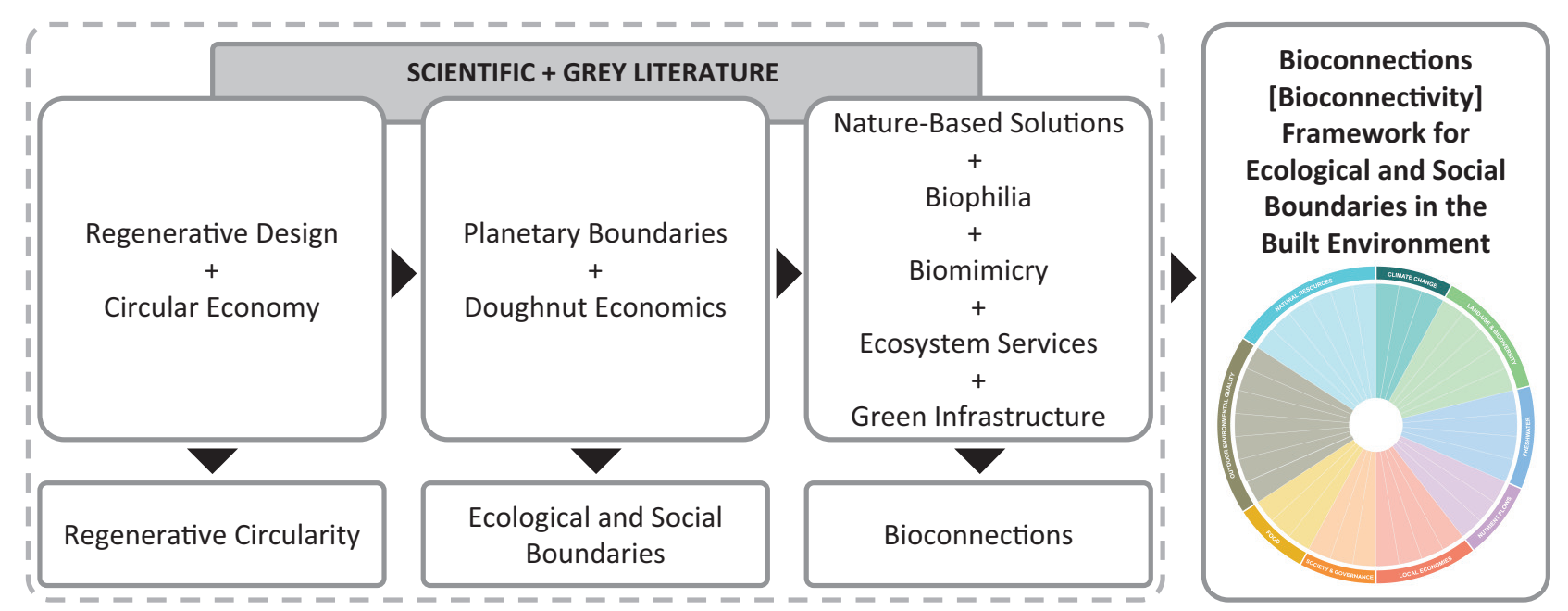

Figure 2. Methodological flowchart. 
Carbon sequestration and storage through photosynthesis, biomass, and soil media are the most straightforward solutions through urban forests (Nowak \& Crane, 2002) and other types of green infrastructure in general (Chen, 2015). In green roofs, plant selection and soil characteristics are key drivers of carbon sequestration (Luo et al., 2015). Indirect contributions may arise from the impact of vegetation on buildings' energy demand for thermal comfort (Shafique et al., 2020).

Algae is a promising resource for energy generation. Microalgae photobioreactors are more efficient than other types of biomass; they also extract nutrients from wastewater, produce oil, and biomass that may be used as biofuel, fertiliser, animal feed, or generate biogas to produce electricity (Elrayies, 2018). In Hamburg's Wilhelmsburg eco-district, the Bio-Intelligent Quotient house (Figure 3 ) is the first bio-reactive panel façade using microalgae and solar thermal energy to generate electricity and heat (IBA Hamburg, 2013), a technology that could be expanded to urban scale applications.

Carbon storage in biobased construction materials by using engineered wood and bamboo from sustainable reforested sources could create carbon pools in cities (Churkina et al., 2020). Comparatively, bamboo products may remove five to six times more carbon from the atmosphere than timber (Hinkle et al., 2019). Long-term management of stored carbon requires life cycle thinking in which buildings are designed for adaptation through modularity, durability, flexibility, and reversibility (Zimmann et al., 2016), thus achieving circularity in construction. It also entails giving new uses for removed urban trees that would otherwise be mulched or burned (Nowak \& Crane, 2002). The treatment of organic waste through composting under adequate conditions is key to reduce the associated greenhouse gases emissions (Zhu-Barker et al., 2017).

\subsection{Land-Use and Biodiversity}

Land-use change and biodiversity loss are strongly connected, e.g., through the conversion of biodiverse areas into farmlands (Norman \& Steffen, 2018). If we are to feed people, we need regenerative farming and permaculture practices in rural areas (Rhodes, 2017).
In cities, the long lifespan of buildings and infrastructure may dictate how they operate for centuries (Floater et al., 2014). Hence, containing urban sprawl with green belts, while finding the right balance between high-quality densification and green spaces, using multifunctional spaces, or even finding voids to add greenery, are challenges to be solved (Haaland \& van den Bosch, 2015). Add to the list preserving and regenerating remnant natural areas and greening every space, from private to public areas, from horizontal to vertical surfaces, either permanently or temporarily (Parris et al., 2018), connecting green patches, and creating conditions for natural processes as pollination, succession, and habitat provision, to thrive (Garrard et al., 2017). The Covid-19 pandemic may present new opportunities to rethink the use of city buildings and public spaces.

In the Bo01 precinct (Figure 4), in Malmö's Västra Hamnen area, Sweden, biodiversity in design was led by two planning instruments, "green space factor" and "green points system," developed for promoting biodiversity, managing stormwater, and creating a healthy neighbourhood (Kruuse, 2011). While the first instrument seeks to increase plots vegetated and permeable areas by achieving a minimum score based on different types of surfaces weighted by their area, the latter increases ecological value by selecting strategies from a pre-determined list to enhance and regenerate local biodiversity and natural cycles. The final design offers multifunctional and liveable urban spaces in contact with nature.

Building facades and lighting have an impact on wildlife, as bird collisions, which could be mitigated by reducing the exposed area of glass and emitted light in facades and adding external elements or printed patterns in glass (Sheppard \& Phillips, 2015). Light pollution also impacts human health and disrupts fauna and flora, demanding attention to the design of façades and outdoor lighting systems (Chepesiuk, 2009).

Pollination is a vital ecosystem service, but its contributions to food security and ecosystem health, mostly by bees, are under threat due to climate change, pesticides, and other causes (Potts et al., 2016). Bees, however, seem to better function in the dynamic of urban environments with reduced use of pesticides, exposed
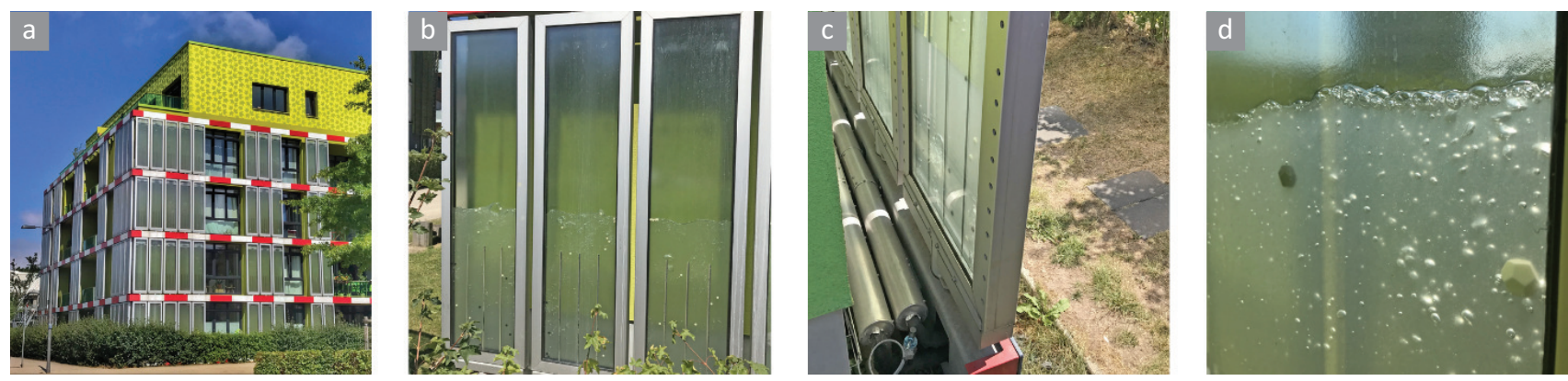

Figure 3. Bio-Intelligent Quotient house in Wilhelmsburg, Hamburg: (a) facades; (b) photobioreactor panels; (c) and (d) details of the photobioreactors. 

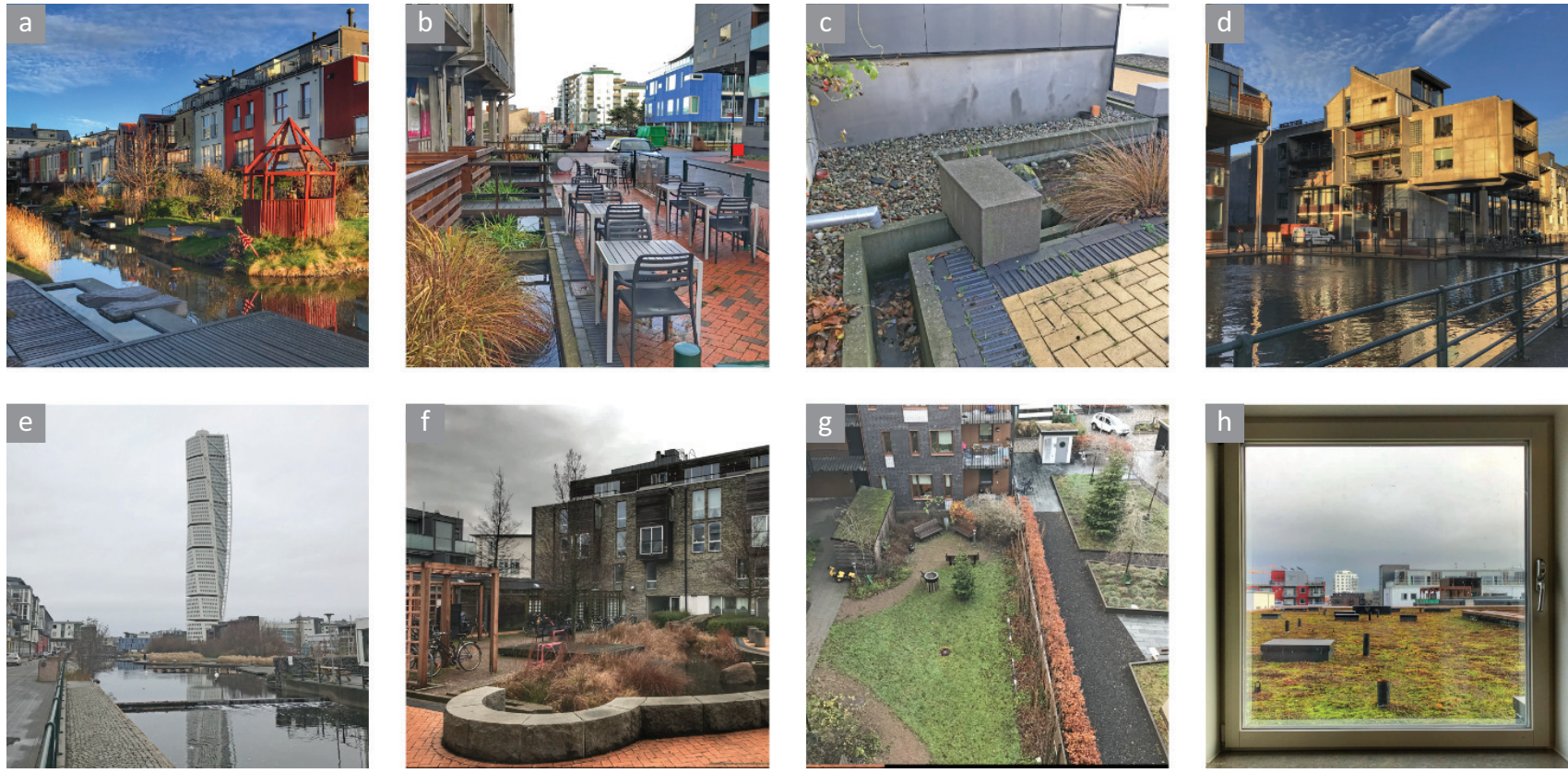

Figure 4. Bo01 precinct in Malmö: (a) Bo01 courtyard with water body; (b) and (c) Bo01 streetscape-integrated elements for stormwater management; (d) and (e) Bo01 water bodies as a part of the urbanscape; (f) and (g) Bo01 courtyard gardens; (h) Bo01 green roof on a residential building.

land, dead wood, cavities in buildings, and continuity of floral resources (Theodorou et al., 2020). In Oslo's Vulkan green precinct, a former industrial area, the importance of bees and pollination led to a beehive at the top of a building (Figure 5), taking advantage of surrounding areas that offer abundant pollen and nectar (Aspelin Ramm, 2015).

\subsection{Freshwater}

Urban freshwater issues relate to direct human consumption, and water embedded in products (Norman \& Steffen, 2018), as well as access, quality, and quantity management. A circular urban approach to water promotes water sensitive cities with a diverse and decentralised infrastructure (Wong \& Brown, 2009). It entails recreating pre-development hydrological conditions (Parris et al., 2018) and protecting and regenerating rivers and other natural sources of water, using sec- ondary sources, in addition to designing water efficient landscapes (Wild et al., 2020). Flood control and water purification through green infrastructures that reduce surface runoff, retain, and infiltrate water (Ely \& Pitman, 2014), and filter diffuse pollution from urban surfaces (Wild et al., 2020). Moreover, constructed wetlands to treat wastewater through phytoremediation processes (Polomski et al., 2007) for reuse.

In São Paulo, Brazil, the Programa Gentileza Urbana (Urban Kindness Programme) uses green infrastructure interventions (Figure 6) to improve permeability in a city constantly battered by floods. According to A. Graziano (personal communication, March 8, 2021), in the period 2019-2020, of the 101 interventions $\left(136,024.00 \mathrm{~m}^{2}\right)$, 65 were raingardens and bioswales, and three conservation woods. The success of the initiative seems to have inspired the city Climate Action Plan, which included nature-based solutions as a strategy to improve stormwater management (Prefeitura do Município de São Paulo,
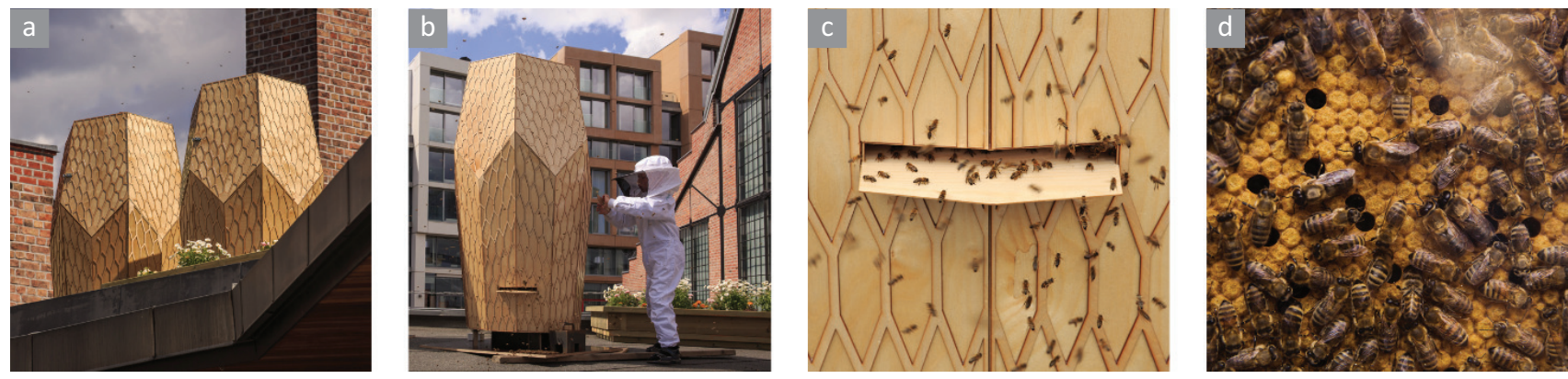

Figure 5. Vulkan precinct in Oslo: (a), (b), (c), and (d) beehive designed by Snøhetta. Source: Photos by Morten Brakestad (2016). 

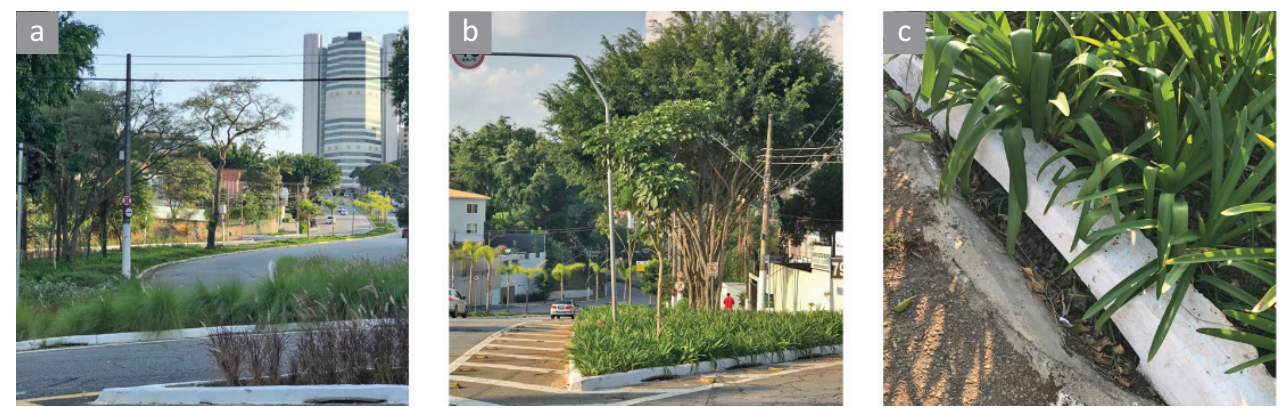

Figure 6. Programa Gentileza Urbana: Interventions in São Paulo; (a) overview of street with rain gardens; (b) a raingarden at the intersection of two streets; (c) kerb detail for water flow.

2021). Moreover, its focus on public areas functions as a complement to the existing "environmental quota" planning instrument aimed only at building plots over $500 \mathrm{~m}^{2}$ : Similarly to Malmö's green space factor, the quota requires new construction projects to achieve a minimum score based on the implementation of green infrastructures to improve local water management, microclimate improvement, and vegetation enhancement (Silva et al., 2017).

\subsection{Nutrient Flows}

Linked to intensive fertiliser use in crops and water bodies' eutrophication, phosphorus and nitrogen are essential for ecosystem productivity and food production (Steffen et al., 2015). Cities' impacts relate to the increasing consumption of food and nutrient flows into receiving waters (Norman \& Steffen, 2018).

Measures include local organic agriculture and closing the loop of nutrients through recovery and management. As the uptake from the atmosphere is limited, one can cultivate nitrogen fixing crops, as legumes, in community gardens (Mendonça et al., 2017). Both nutrients can be recovered from wastewater treatment with constructed wetlands (Polomski et al., 2007), strategies that could be boosted with a georeferenced identification of hotspots for intervention (Wielemaker et al., 2020). The use of compost from organic waste promotes nutrient cycling (Shrestha et al., 2020) in urban and rural agriculture; however, rooftop farming requires extra attention to reduce nutrient loss to storm drains (Harada et al., 2018).

\subsection{Natural Resources}

In addition to circular design principles (Zimmann et al., 2016) for the biological and technical cycles of resources, bioconnections to reduce the material footprint and improve resource use include:

- Regenerative and circular procurement guidelines (Volans, 2020);

- Sustainable sourcing of biological and technical resources, as mining has large impacts on rainforests (Sonter et al., 2017);
- Prioritise biobased alternatives as wood and bamboo (Churkina et al., 2020), mycelium and hempcrete (Blok et al., 2019), and plant-based alternatives to animal leather;

- "Industrial symbiosis" through infrastructure sharing or exchange of by-products (Rosado \& Kalmykova, 2019);

- Long-term resource planning through buildings as materials banks and materials passports for resource traceability (Debacker \& Manshoven, 2016), and trade of recovered products using digital marketplaces.

\subsection{Outdoor Environmental Quality}

Outdoor environmental quality is about the various outdoor aspects which "which have an impact on the health, comfort or wellbeing of the occupants and neighbours" (HKGBC, n.d.). Here, it is explored through six parameters: air quality, thermal comfort, soundscape, visual comfort, proxemics, and beauty \& quality, defined below.

Although DE normally depicts health separately, here we see it as a result of outdoor environmental quality and other ecological and social boundaries under the lenses of positive health, drawing upon six pillars: mental wellbeing, meaningfulness, quality of life, social-societal participation, daily functioning, and bodily functions (Institute for Positive Health, 2017). As compiled by van den Bosch and Ode Sang (2017), there is extensive research and evidence that nature-based solutions may influence health through many physical and mental variables.

\subsubsection{Air Quality}

Air pollution is one of the biggest urban threats to health. Although it needs to be solved at the source, plants have a cleansing ability by retaining, absorbing, and transforming pollutants in the air, soil, and water (Dicks et al., 2020). Different green infrastructure elements and configurations, however, offer different capabilities that need context-based consideration (Abhijith et al., 2017). Take moss, for instance, and its relatively high potential for air pollutant removal (Donateo et al., 2021), as the structure installed in London (Figure 7). Vegetation 

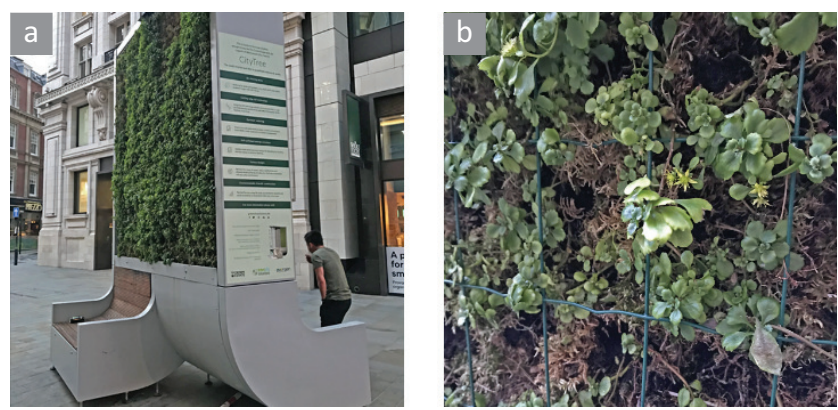

Figure 7. CityTree moss vertical infrastructure in London: (a) general view; (b) detail of moss and plants arrangement.

selection for green infrastructure, nonetheless, needs attention to avoid some potential associated disservices related to pollen and the emission of biogenic volatile organic compounds by some species that react with NOx and solar radiation, creating ozone and deteriorating air quality (Leung et al., 2011).

\subsubsection{Thermal Comfort}

Urbanised environments tend to be warmer than their rural surroundings due to the urban heat island effect (T. R. Oke, 1978). This phenomenon, intensified by climate change, harms health, and increases energy consumption for building cooling (Santamouris, 2014). The benefits of bioclimatic architecture and urban design integrated with green infrastructure, and the resulting microclimate modification ecosystem services are widely known (Battisti, 2020). However, the wide continuum of green infrastructure typologies, from green open spaces to water bodies, to tree canopies, as well as green roofs and vertical greenery systems (Bartesaghi Koc et al., 2017) leads to diverse effects, requiring a context-based look in each intervention.

\subsubsection{Soundscape}

When looking into acoustic issues, we usually emphasise the reduction of noise nuisances in built environment, rather than designing high-quality soundscapes that could positively impact our perception and understanding of the acoustic environment (International Standard Organisation, 2014). Through adequate design, vegetation may provide benefits as insulation and sound scattering (Yang et al., 2013), and natural sounds may generate a pleasant acoustic environment, mask noises, and contribute to stress reduction (Semidor \& Venit-Gbedji, 2009).

\subsubsection{Visual Comfort}

Visual comfort may be disrupted by the excess or lack of light during day or night in various situations. Glare, for instance, may be reduced or eliminated with adequate positioning of vegetation barriers and surface covering (Kocur-Bera \& Dudzinska, 2015).

\subsubsection{Proxemics}

Proxemics, "the study of man's perception and use of space" (Hall et al., 1968, p. 83), is linked to bioconnections through the design and organisation of nature in public areas that adds variety and options to facilitate citizens' interaction or isolation. During the Covid-19 pandemic, the need for accessible green infrastructures, in which contact with nature while maintaining social distancing is possible, grew stronger, indicating different types, sizes, and uses of green infrastructures are needed (Ugolini et al., 2020).

\subsubsection{Beauty and Quality}

Beauty, seen in the "Living Community Challenge" scheme not from a single perspective imposed onto others, but as an acknowledgement of its diverse possibilities, is "a precursor to caring enough to preserve, conserve and serve the greater good" (International Living Future Institute, 2017, p. 53). The scheme suggests, as one of the strategies, the presence of art installations in public spaces. The consideration of available views, materials used, water fountains, and other visual elements, in addition to year-round vegetation (Knobel et al., 2021), as well as varying degrees of tamed or wild landscapes (WHO Regional Office for Europe, 2016), also impacts the perception of beauty.

Regarding quality, in addition to adequate maintenance and perceived level of fauna and flora biodiversity (WHO Regional Office for Europe, 2016), B. Chen et al. (2009) suggest factors as varied as auditory, olfactory, tactile, and visual elements should be considered. Du et al. (2016) indicate the diversity of vegetation structure and height, the presence of dominant trees, planting density, colour contrast, and species number. Finally, de la Barrera et al. (2016) imply beauty depends on the green infrastructure size, shape, and vegetation cover.

\subsection{Food}

Food production is strongly dependent on rural areas. Organic urban farming on public and private land, abandoned areas, and horizontal and vertical surfaces (Parris et al., 2018) could reduce this dependency and facilitate 
access to healthy food, reducing food poverty, and increasing food security, particularly in face of extreme events. A regenerative and circular urban approach to food promotes healthier lifestyles, encourages community engagement (Enssle \& Kabisch, 2020), reduces waste, and regenerates natural cycles (Raworth, 2017) through composting, biogas production, and synergies with pollination (Ellen MacArthur Foundation, 2019).

An ecological favela may seem like an oxymoron, but the history of Vila Nova Esperança, an informal settlement in São Paulo, exemplifies the power of nature and local food production. The community avoided expropriation through their environmental approach to land (Figure 8): an organic food garden for all residents, a community centre with a collective kitchen, and interventions to reduce geological risks. These are some of the actions strengthening community engagement and regeneration of an underprivileged area, generating benefits to their daily lives in what they now consider an "ecological village" (L. Esperança, personal communication, November 29, 2019).

\subsection{Local Economies}

A regenerative and circular economy sees businesses as nodes of a complex value network (Volans, 2020) that offers more than just products and services (Driesenaar, 2019). They foster distributive and local economies (Raworth, 2017) that create positive impacts on nature and communities. Expanding on Samset and Accorigi (2020) and Taylor Buck and While (2021), an "urban circular bioeconomy" can be understood as the valorisation of primary and secondary biological resources in cities in the form of services and products that generate direct and indirect benefits to the economy and the society in the present and future.

This could be achieved through food gardens with free or low-cost access to the production and space, produce selling in local shops and marketplaces at fair prices, besides jobs for the maintenance of green spaces. Waste and resource exchange through "industrial symbiosis" could also connect local producers (Rosado \& Kalmykova, 2019). Indirect contributions to local economies may come through the ecosystem ser- vices valuation of urban green infrastructure (Elmqvist et al., 2015) that could support financial mechanisms as green or climate bonds (Bernknopf \& Broadbent, Craig, 2020) and improve green property taxes. Regenerative and circular neighbourhoods could also boost the local economy by attracting tourism (Parris et al., 2018). Given the possibility of green infrastructures raising the price of properties (Swinbourne \& Rosenwax, 2017), careful attention must be given to avoid gentrification processes (Ehrmann, 2018).

An "open-source circular design," in which a collaborative, shared, and transparent development and use of ideas merged with the principles of circular economy (Open Source Circular Economy Days, 2016) has the potential to decentralise the design and production of goods, facilitating a distributive economy that emphasises local businesses rather than big corporations (Raworth, 2017).

\subsection{Society and Governance}

Different boundaries as social equity, social networks, political voice, and access to infrastructures may be merged under the umbrella of society and governance. There are two important aspects to foster those different issues; one is about planning cities for all and by alli.e., considering that cities should be for all citizens, and more than that, engaging the different social groups in this process. Another aspect is access to all basic infrastructure, which includes nature, or green infrastructure. Normally the main indicator considered in some municipalities, access is an important factor towards urban green equity (de la Barrera et al., 2016; Nesbitt et al., 2018), and WHO Regional Office for Europe (2016) suggests residences should be located within a $300 \mathrm{~m}$ linear distance, or 5 min walking, from a green space.

The strengthening of social networks and cohesion has been associated with green infrastructures, particularly for older citizens, and can be enhanced by ensuring "universal design" and spaces for different age groups (Enssle \& Kabisch, 2020). Adequate engagement of citizens and participatory governance is essential to ensure political voice (Nesbitt et al., 2018). One example is the City of Melbourne (2017) "urban forester" programme,
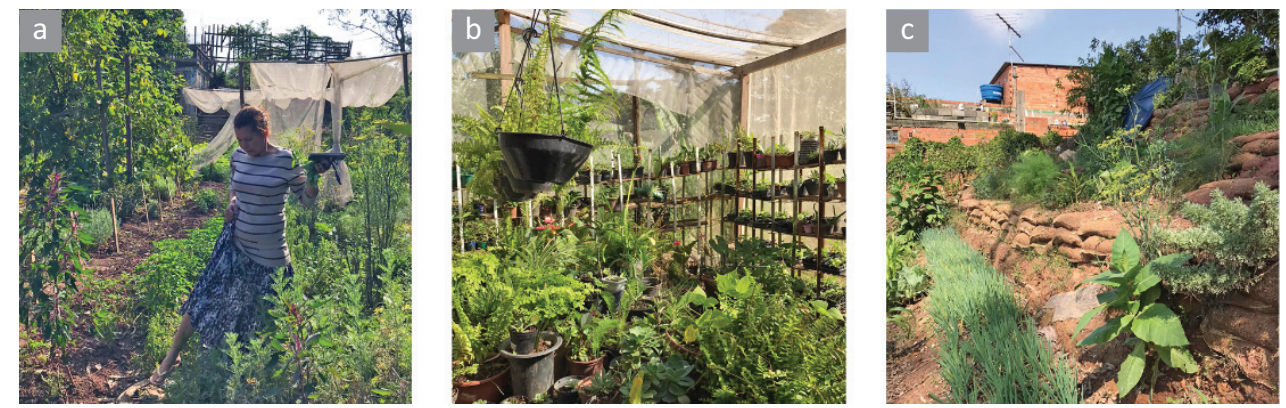

Figure 8. Vila Nova Esperança, São Paulo: (a) community leader Lia Esperança in the organic food garden; (b) greenhouse; (c) slope intervention. 
which engages citizens in the development of science through data collection, planning, and other initiatives.

\section{Discussion}

We prepared a framework summarising relevant bioconnections for each social and ecological boundary (Figure 9) discussed above. On close examination, the multidimensional effects of their ecosystem services across boundaries become clear. This reflects the multifunctional roles of green compared to hard infrastructure (Ely \& Pitman, 2014), and the inherent systemic nature of regenerative design and circular economy There are cases, however, where a mixed green-grey infrastructure delivers optimised outcomes to increase resilience (Ely \& Pitman, 2014). More than just bene- fits for human society, they have potential to produce a positive impact to both human and the planet in the short and long-term. Nevertheless, careful planning and design of solutions is needed to avoid potential disservices or ineffectiveness (Leung et al., 2011; van den Bosch \& Ode Sang, 2017). This "systems thinking" also translates in the need to engage different sectors and actors, as collaboration is a key concept to circular economy (Ellen MacArthur Foundation, 2019). In that matter, and in line with society and governance, evidence suggests that reduced or no engagement from communities in decision-making processes may lead to poorer results of interventions (Roe et al., 2021).

New neighbourhoods, like Bo01, demonstrate the significance of putting bioconnectivity at the core early in the process. Initiatives like Gentileza Urbana showcase

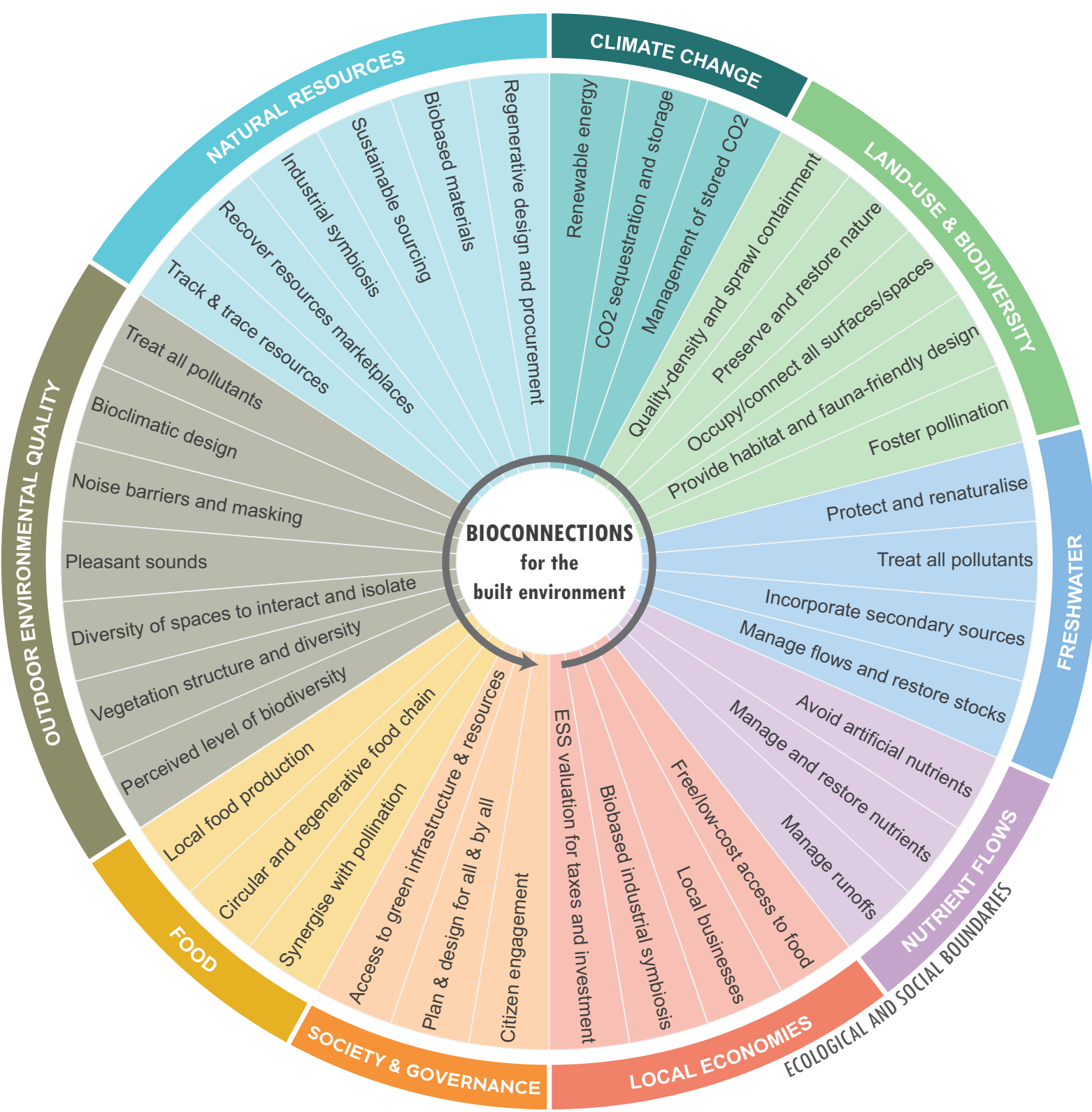

Figure 9. Bioconnections framework for ecological and social boundaries under a regenerative and circular approach for the built environment. 
the potential to regenerate the building stock of our cities and open the discussion about high-quality densification and green areas, so that we reach a balance and start reconverting urban voids and underutilised buildings and urban spaces. In any case, policies are important enablers to define the rules and implement financial incentives to initiate implementation.

From an economic point of view, the World Economic Forum indicates that a nature-focused approach to cities could generate US\$3 trillion of annual business opportunities and 117 million jobs by 2030 (World Economic Forum, 2020). Bioconnections have the potential to bring nature into cities, increasing resilience, and providing liveable urban spaces with a positive impact on health and social aspects.

\section{Conclusions}

In this article, we have argued that the current linear approaches to sustainability are not enough in light of the environmental and social challenges of cities. Acknowledging the importance to learn from nature and its multidimensional benefits to both natural and human-made environments, we proposed the adoption of bioconnections as enablers of a "regenerative circularity" for the BE. Reinterpreting the DE of ecological and social boundaries (Raworth, 2017) for a built environment context, we examined and discussed the literature to identify relevant interventions, solutions, or strategies. A resulting bioconnections framework was prepared to illustrate the wide range of possibilities that could facilitate the transition to regenerative and circular cities, hence, seeking to address Buchmann-Duck and Beazley (2020) call for a stronger biodiversity inclusion in circular economy studies. Global examples of green neighbourhoods and interventions demonstrated the technical feasibility of implementing bioconnections and the importance of policies to foster nature-focused interventions in cities, as argued by Parris et al. (2018).

One should have in mind the impossibility of fully restoring urban areas and their urban biodiversity to a pre-development condition. Regenerating is not about a return to a nostalgic past, but rather about creating a new and generous future in which, in symbiosis with nature, we create value and positive impact for the planet and its human and non-human inhabitants. Hence, the increasing need to incorporate nature's knowledge as a tool to improve urban areas and address the increasing social and environmental challenges. As we enter the "decade (2021-2030) on ecosystem restoration" (United Nations, 2019), that becomes increasingly imperative. In that light, the contribution of this article is twofold:

a. It presents a nature-based response to the PB and DE models of ecological and social boundaries from a local scale and built environment perspective; b. It offers a bioconnections framework for the development of new urban areas or transition of existing ones under regenerative and circular lenses.

Future research could benefit from a more in-depth examination of how local policies may hinder or foster bioconnections and how they incorporate ecological and social boundaries. Defining indicators may also support measuring the actual contribution of the proposed solutions both in isolation and combined, particularly to better understand their synergies and trade-offs.

\section{Acknowledgments}

The lead author (HSB) acknowledges the support of a University International Postgraduate Award from the University of New South Wales. The authors sincerely thank the anonymous reviewers and the editor for their valuable suggestions and comments.

\section{Conflict of Interests}

The authors declare no conflict of interests.

\section{References}

Abhijith, K. V., Kumar, P., Gallagher, J., McNabola, A., Baldauf, R., Pilla, F., Broderick, B., Di Sabatino, S., \& Pulvirenti, B. (2017). Air pollution abatement performances of green infrastructure in open road and built-up street canyon environments-A review. Atmospheric Environment, 162, 71-86. https://doi. org/10.1016/j.atmosenv.2017.05.014

Aspelin Ramm. (2015). Sustainable urban development project: Vulkan, Oslo. https://aspelinramm. headingnorth.at/vulkanoslo.no/wp-content/ uploads/20151118-Vulkanfolder-eng-02.pdf

Bartesaghi Koc, C., Osmond, P., \& Peters, A. (2017). Towards a comprehensive green infrastructure typology: A systematic review of approaches, methods and typologies. Urban Ecosystems, 20(1), 15-35. https://doi.org/10.1007/s11252-016-0578-5

Battisti, A. (2020). Bioclimatic architecture and urban morphology. Studies on intermediate urban open spaces. Energies, 13(21), Article 5819. https://doi. org/10.3390/en13215819

Benyus, J. (2015). The generous city. Architectural Design, 85(4), 120-121. https://doi.org/10.1002/ad. 1939

Bernknopf, R. L., \& Broadbent, C. D. (2020). Estimating forest sustainability bond prices for natural resource and ecosystem services markets. The Journal of Environmental Investigation, 10(1). https://www. thejei.com/estimating-forest-sustainability-bondprices-for-natural-resource-and-ecosystem-servicesmarkets

Birkeland, J. (2019). Net-positive design and sustainable urban development (1st ed.). Routledge. 
Blok, R., Kuit, B., Schröder, T., \& Teuffel, P. (2019). Biobased construction materials for a sustainable future. In 20th Congress of IABSE, New York City 2019: The Evolving Metropolis-Report (pp. 860-866). Eindhoven University of Technology.

Boulding, K. E. (2011). The economics of the coming spaceship Earth. In H. Jarrett \& K. E. Boulding (Eds.), Environmental and resource economics: Vol. 3. Environmental quality in a growing economy (pp. 3-14). Earthscan. (Original work published 1966)

Brakestad, M. (2016). Snøhetta beehives at Vulkan, Oslo. Morten Brakestad Photography. https:// brakestad.photoshelter.com/gallery/Snohettabeehives-at-Vulkan-Oslo/G0000A7xu1Li4Dks

Buchmann-Duck, J., \& Beazley, K. F. (2020). An urgent call for circular economy advocates to acknowledge its limitations in conserving biodiversity. The Science of the Total Environment, 727, Article 138602. https:// doi.org/10.1016/j.scitotenv.2020.138602

Calisto Friant, M., Vermeulen, W. J., \& Salomone, R. (2020). A typology of circular economy discourses: Navigating the diverse visions of a contested paradigm. Resources, Conservation and Recycling, 161, Article 104917. https://doi.org/10.1016/ j.resconrec.2020.104917

Chapin, F. S., Zavaleta, E. S., Eviner, V. T., Naylor, R. L., Vitousek, P. M., Reynolds, H. L., Hooper, D. U., Lavorel, S., Sala, O. E., Hobbie, S. E., Mack, M. C., \& Díaz, S. (2000). Consequences of changing biodiversity. Nature, 405(6783), 234-242. https://doi.org/ $10.1038 / 35012241$

Chen, B., Adimo, O. A., \& Bao, Z. (2009). Assessment of aesthetic quality and multiple functions of urban green space from the users' perspective: The case of Hangzhou Flower Garden, China. Landscape and Urban Planning, 93(1), 76-82. https://doi.org/ 10.1016/j.landurbplan.2009.06.001

Chen, W. Y. (2015). The role of urban green infrastructure in offsetting carbon emissions in 35 major Chinese cities: A nationwide estimate. Cities, 44, 112-120. https://doi.org/10.1016/j.cities.2015.01. 005

Chepesiuk, R. (2009). Missing the dark: Health effects of light pollution. Environmental Health Perspectives, 117(1), 20-27. https://doi.org/10.1289/ehp. 117-a20

Churkina, G., Organschi, A., Reyer, C. P. O., Ruff, A., Vinke, K., Liu, Z., Reck, B. K., Graedel, T. E., \& Schellnhuber, H. J. (2020). Buildings as a global carbon sink. Nature Sustainability, 3(4), 269-276. https://doi.org/ 10.1038/s41893-019-0462-4

Circle Economy. (2021). The circularity gap report: 2021. https://www.circularity-gap.world/2021

City of Melbourne. (2017). Become a citizen forester. https://www.melbourne.vic.gov.au/community/ greening-the-city/urban-forest/Pages/become-acitizen-forester.aspx

de la Barrera, F., Reyes-Paecke, S., \& Banzhaf, E. (2016).
Indicators for green spaces in contrasting urban settings. Ecological Indicators, 62, 212-219. https://doi. org/10.1016/j.ecolind.2015.10.027

DEAL, Biomimicry 3.8, C40 Cities, \& Circle Economy. (2020). Creating City Portraits: A methodological guide from The Thriving Cities Initiative. https:// doughnuteconomics.org/Creating-City-PortraitsMethodology.pdf

Debacker, W., \& Manshoven, S. (2016). D1 synthesis report on state-of-the-art analysis: Key barriers and opportunities for materials passports and reversible building design in the current system. BAMB Project-Building as Material Banks. http://www. bamb2020.eu/wp-content/uploads/2016/03/D1_ Synthesis-report-on-State-of-the-art_20161129_ FINAL.pdf

Desing, H., Brunner, D., Takacs, F., Nahrath, S., Frankenberger, K., \& Hischier, R. (2020). A circular economy within the planetary boundaries: Towards a resourcebased, systemic approach. Resources, Conservation and Recycling, 155, Article 104673. https://doi.org/ 10.1016/j.resconrec.2019.104673

Dicks, J., Dallaccio, O., \& Stenning, J. (2020). Economic costs and benefits of nature-based solutions to mitigate climate change (Final report). Cambridge Econometrics. https://www.rspb.org.uk/ globalassets/downloads/documents/positions/ the-economic-costs- $\bigvee$-benefits-of-nature-basedsolutions_final-report_final_v3.pdf

Donateo, A., Rinaldi, M., Paglione, M., Villani, M. G., Russo, F., Carbone, C., Zanca, N., Pappaccogli, G., Grasso, F. M., Busetto, M., Sänger, P., Ciancarella, L., \& Decesari, S. (2021). An evaluation of the performance of a green panel in improving air quality, the case study in a street canyon in Modena, Italy. Atmospheric Environment, 247, Article 118189. https:// doi.org/10.1016/j.atmosenv.2021.118189

Driesenaar, D. (2019). Business models: from linear to circular to regenerative. Medium. https://medium. com/swlh/business-models-from-linear-to-circularto-regenerative-9f10c19f337

Du, H., Jiang, H., Song, X., Zhan, D., \& Bao, Z. (2016). Assessing the visual aesthetic quality of vegetation landscape in urban green space from a visitor's perspective. Journal of Urban Planning and Development, 142(3), Article 4016007. https://doi.org/ 10.1061/(ASCE)UP.1943-5444.0000329

Ehrmann, S. (2018, November 29). Green gentrification and how to avoid it. Foreground. https://www. foreground.com.au/parks-places/green-gentrification

Ellen MacArthur Foundation. (2013). Towards the circular economy: Economic and business rationale for an accelerated transition (Vol. 1). https:// ellenmacarthurfoundation.org/towards-thecircular-economy-vol-1-an-economic-and-businessrationale-for-an

Ellen MacArthur Foundation. (2019). Cities and circular economy for food. https://ellenmacarthur 
foundation.org/cities-and-circular-economy-for-food

Ellen MacArthur Foundation. (2020, June). A solution to build back better: the circular economy [Press release]. https://ellenmacarthurfoundation. org/news/its-time-to-step-up-not-step-back

Ellis, E. C., \& Ramankutty, N. (2008). Putting people in the map: Anthropogenic biomes of the world. Frontiers in Ecology and the Environment, 6(8), 439-447. https://doi.org/10.1890/070062

Elmqvist, T., Setälä, H., Handel, S. N., van der Ploeg, S., Aronson, J., Blignaut, J. N., Gómez-Baggethun, E., Nowak, D. J., Kronenberg, J., \& de Groot, R. (2015). Benefits of restoring ecosystem services in urban areas. Current Opinion in Environmental Sustainability, 14, 101-108. https://doi.org/10.1016/j.cosust. 2015.05.001

Elrayies, G. M. (2018). Microalgae: Prospects for greener future buildings. Renewable and Sustainable Energy Reviews, 81, 1175-1191. https://doi.org/10.1016/ j.rser.2017.08.032

Ely, M., \& Pitman, S. (2014). Green infrastructure: Life support for human habitats. Botanic Gardens of South Australia.

Enssle, F., \& Kabisch, N. (2020). Urban green spaces for the social interaction, health and well-being of older people-An integrated view of urban ecosystem services and socio-environmental justice. Environmental Science \& Policy, 109, 36-44. https://doi.org/ 10.1016/j.envsci.2020.04.008

European Commission. (2019, December 11). Communication from the Commission to the European Parliament, the European Council, the Council, the European Economic and Social Committee and the Committee of The Regions: The European Green Deal (COM/2019/640 final). https://eur-lex.europa. eu/legal-content/EN/TXT/?uri=COM\%3A2019\% 3A640\%3AFIN

European Commission. (2020). Circular economy action plan: For a cleaner and more competitive Europe. https://ec.europa.eu/environment/circulareconomy/pdf/new_circular_economy_action_ plan.pdf

Floater, G., Rode, P., Robert, A., Kennedy, C., Hoornweg, D., Slavcheva, R., \& Godfrey, N. (2014). Cities and the new climate economy: The transformative role of global urban growth (New Climate Economy Paper No. 01). LSE Cities; London School of Economics and Political Science. https://Isecities.net/wp-content/ uploads/2014/12/The-Transformative-Role-ofGlobal-Urban-Growth-01.pdf

Fuller, R. B. (1969). Operating manual for spaceship Earth. Lars Muller.

Garrard, G. E., Williams, N. S. G., Mata, L., Thomas, J., \& Bekessy, S. A. (2017). Biodiversity sensitive urban design. Conservation Letters, 11(2), Article e12411. https://doi.org/10.1111/conl.12411

Haaland, C., \& van den Bosch, C. K. (2015). Challenges and strategies for urban green-space planning in cities undergoing densification: A review. Urban Forestry \& Urban Greening, 14(4), 760-771. https:// doi.org/10.1016/j.ufug.2015.07.009

Hall, E. T., Birdwhistell, R. L., Bock, B., Bohannan, P., Diebold, A. R., Durbin, M., Edmonson, M. S., Fischer, J. L., Hymes, D., Kimball, S. T., La Barre, W., McClellan, J. E., Marshall, D. S., Milner, G. B., Sarles, H. B., Trager, G. L., \& Vayda, A. P. (1968). Proxemics [and Comments and Replies]. Current Anthropology, 9(2/3), 83-108. https://doi.org/10.1086/200975

Harada, Y., Whitlow, T. H., Templer, P. H., Howarth, R. W., Walter, M. T., Bassuk, N. L., \& Russell-Anelli, J. (2018). Nitrogen biogeochemistry of an urban rooftop farm. Frontiers in Ecology and Evolution, 6, Article 153. https://doi.org/10.3389/fevo.2018.00153

Hinkle, H., McGinley, M., Hargett, T., \& Dascher, S. (2019). Carbon farming with timber bamboo: $A$ superior sequestration system compared to wood. Why the time is now for the world to take advantage of nature's fastest growing structural fiber. BamCore. https://bamcore.com/wp-content/uploads/2019/ 01/Carbon-Farming-with-Timber-Bamboo.pdf

HKGBC. (n.d.). Assessment aspects-How does BEAM Plus assess? Hong Kong Green Building Council. http://greenbuilding.hkgbc.org.hk/posts/view/ BEAMPlus_AssessmentAspects

Hoornweg, D., Hosseini, M., Kennedy, C., \& Behdadi, A. (2016). An urban approach to planetary boundaries. Ambio, 45(5), 567-580. https://doi.org/ 10.1007/s13280-016-0764-y

Hoornweg, D., Sugar, L., \& Trejos Gómez, C. L. (2011). Cities and greenhouse gas emissions: Moving forward. Environment and Urbanization, 23(1), 207-227. https://doi.org/10.1177/0956247810392270

IBA Hamburg. (2013). Smart material house BIQ. https:// www.internationale-bauausstellung-hamburg.de/ fileadmin/Slideshows_post2013/02_Wissen/ 01_Whitepaper/130716_White_Paper_BIQ_en.pdf

Institute for Positive Health. (2017). Pillars for positive health. https://www.iph.nl/assets/uploads/2020/ 12/MyPositiveHealth-dialogue-tool.pdf

International Living Future Institute. (2017). Living Community Challenge 1.2. https://living-future.org/ wp-content/uploads/2019/08/Living-CommunityChallenge-1-2.pdf

International Standard Organisation. (2014). 129131:2014 Acoustics soundscape-Part 1: Definition and conceptual framework.

International Union for Conservation of Nature. (2016). Defining nature-based solutions (WCC-2016-Res-069EN). International Union for Conservation of Nature. https://portals.iucn.org/library/sites/library/files/ resrecfiles/WCC_2016_RES_069_EN.pdf

IRP. (2018). The weight of cities: Resource requirements of future urbanization (Full report). International Resource Panel; UN Environment Programme.

IRP. (2019). Global resources outlook 2019: Natural resources for the future we want. International 
Resource Panel; UN Environment Programme. https://www.resourcepanel.org/reports/globalresources-outlook

Kellert, S., \& Wilson, E. O. (Eds.). (1993). The biophilia hypothesis. Island Press/Shearwater Books.

Knobel, P., Dadvand, P., Alonso, L., Costa, L., Español, M., \& Maneja, R. (2021). Development of the urban green space quality assessment tool (RECITAL). Urban Forestry \& Urban Greening, 57, Article 126895. https://doi.org/10.1016/j.ufug.2020.126895

Kocur-Bera, K., \& Dudzinska, M. (2015). Roadside vegetation-The impact on safety. In 14th International Scientific Conference Engineering for Rural Development. Jelgava, Latvia. May 20-22 (pp. 594-600). Latvia University of Agriculture.

Kruuse, A. (2011). The green space factor and the green points system (GRaBS Expert Paper No. 6). Town and Country Planning Association. https:// nextcity.nl/wp-content/uploads/2017/01/1701256Malmoe-Tools-c-Annika-Kruuse.pdf

Leung, D. Y. C., Tsui, J. K. Y., Chen, F., Yip, W.-K., Vrijmoed, L. L. P., \& Liu, C.-H. (2011). Effects of urban vegetation on urban air quality. Landscape Research, 36(2), 173-188. https://doi.org/10.1080/01426397. 2010.547570

Lucas, P., \& Wilting, H. (2018). Using planetary boundaries to support national implementation of environment-related sustainable development goals (Background report). PBL Netherlands Environmental Assessment Agency. https://www.pbl.nl/sites/ default/files/downloads/Using_planetary_ boundaries_to_support_national_implementation_ of_environment-related_Sustainable_Development_ Goals_-_2748.pdf

Luo, H., Liu, X., Anderson, B. C., Zhang, K., Li, X., Huang, B., Li, M., Mo, Y., Fan, L., Shen, Q., Chen, F., \& Jiang, M. (2015). Carbon sequestration potential of green roofs using mixed-sewage-sludge substrate in Chengdu World Modern Garden City. Ecological Indicators, 49, 247-259. https://doi.org/10.1016/j.ecolind.2014.10. 016

Lyle, J. T. (1994). Regenerative design for sustainable development. Wiley.

Mang, P., \& Reed, B. (2012). Regenerative development and design. In R. A. Meyers (Ed.), Encyclopedia of sustainability science and technology (pp. 8855-8879). Springer. https://doi.org/10.1007/9781-4419-0851-3_303

Mendonça, E. de S., Lima, P. C. de, Guimarães, G. P., Moura, W. de M., \& Andrade, F. V. (2017). Biological nitrogen fixation by legumes and $\mathrm{N}$ uptake by coffee plants. Revista Brasileira de Ciência Do Solo, 41(0). https://doi.org/10.1590/18069657rbcs20160178

Millennium Ecosystem Assessment. (2005). Ecosystems and human well-being: Synthesis. Island Press.

Murphy, S. (2015). What's the difference between regeneration and restoration? Regenesis Group. https:// regenesisgroup.com/regeneration-vs-restoration
Naumann, S., Davis, M., Kaphengst, T., Pieterse, M., \& Rayment, M. (2011). Design, implementation and cost elements of green infrastructure projects (Final report). http://ec.europa.eu/environment/enveco/ biodiversity/pdf/GI_DICE_FinalReport.pdf

Nesbitt, L., Meitner, M. J., Sheppard, S. R., \& Girling, C. (2018). The dimensions of urban green equity: A framework for analysis. Urban Forestry \& Urban Greening, 34, 240-248. https://doi.org/10.1016/ j.ufug.2018.07.009

Norman, B., \& Steffen, W. (2018). Planning within planetary boundaries. In B. Norman (Ed.), Routledge studies in sustainable development. Sustainable pathways for our cities and regions: Planning within planetary boundaries (1st ed., pp. 20-44). Routledge.

Nowak, D. J., \& Crane, D. E. (2002). Carbon storage and sequestration by urban trees in the USA. Environmental Pollution, 116(3), 381-389. https://doi. org/10.1016/S0269-7491(01)00214-7

O’Neill, D. W., Fanning, A. L., Lamb, W. F., \& Steinberger, J. K. (2018). A good life for all within planetary boundaries. Nature Sustainability, 1(2), 88-95. https://doi. org/10.1038/s41893-018-0021-4

Oke, C., Bekessy, S. A., Frantzeskaki, N., Bush, J., Fitzsimons, J. A., Garrard, G. E., Grenfell, M., Harrison, L., Hartigan, M., Callow, D., Cotter, B., \& Gawler, S. (2021). Cities should respond to the biodiversity extinction crisis. npj Urban Sustainability, 1, Article 11. https://doi.org/10.1038/s42949-020-00010-w

Oke, T. R. (1978). Boundary layer climates. Routledge.

Open Source Circular Economy Days. (2016). Mission statement. https://web.archive.org/web/20160425 133055/https://oscedays.org/open-source-circulareconomy-mission-statement

Parris, K. M., Amati, M., Bekessy, S. A., Dagenais, D., Fryd, O., Hahs, A. K., Hes, D., Imberger, S. J., Livesley, S. J., Marshall, A. J., Rhodes, J. R., Threlfall, C. G., Tingley, R., van der Ree, R., Walsh, C. J., Wilkerson, M. L., \& Williams, N. S. G. (2018). The seven lamps of planning for biodiversity in the city. Cities, 83, 44-53. https://doi.org/10.1016/j.cities.2018.06.007

Pearce, D. W., \& Turner, R. K. (1989). Economics of natural resources and the environment. The Johns Hopkins University Press.

Pedersen Zari, M. (2012). Ecosystem services analysis for the design of regenerative built environments. Building Research \& Information, 40(1), 54-64. https:// doi.org/10.1080/09613218.2011.628547

Pedersen Zari, M. (2015). Ecosystem services analysis: Mimicking ecosystem services for regenerative urban design. International Journal of Sustainable Built Environment, 4(1), 145-157. https://doi.org/10.1016/ j.ijsbe.2015.02.004

Pedersen Zari, M. (2017a). Biomimetic urban design: Ecosystem service provision of water and energy. Buildings, 7(1), Article 21. https://doi.org/10.3390/ buildings7010021

Pedersen Zari, M. (2017b). Ecosystem services analy- 
sis: incorporating an understanding of ecosystem services into built environment design and materials selection. In Materials for a Healthy, Ecological and Sustainable Built Environment (pp. 29-63). Elsevier. https://doi.org/10.1016/B978-0-08-100707-5. 00002-2

Polomski, R. F., Bielenberg, D. G., Whitwell, T., Taylor, M. D., Bridges, W. C., \& Klaine, S. J. (2007). Nutrient recovery by seven aquatic garden plants in a laboratory-scale subsurface-constructed wetland. HortScience, 42(7), 1674-1680. https://doi.org/ 10.21273/HORTSCI.42.7.1674

Potts, S. G., Imperatriz-Fonseca, V., Ngo, H. T., Aizen, M. A., Biesmeijer, J. C., Breeze, T. D., Dicks, L. V., Garibaldi, L. A., Hill, R., Settele, J., \& Vanbergen, A. J. (2016). Safeguarding pollinators and their values to human well-being. Nature, 540(7632), 220-229. https://doi.org/10.1038/nature20588

Prefeitura do Município de São Paulo. (2021). PlanClimaSP: Plano de ação climática do município de São Paulo 2020-2050 [São Paulo municipality climate action plan 2020-2050]. https://www.prefeitura.sp. gov.br/cidade/secretarias/upload/meio_ambiente/ arquivos/PlanClimaSP_BaixaResolucao.pdf

Raworth, K. (2017). Doughnut economics: Seven ways to think like a 21st century economist. Chelsea Green Publishing

Reed, B. (2007). Shifting from 'sustainability' to regeneration. Building Research \& Information, 35(6), 674-680. https://doi.org/10.1080/0961321070147 5753

Rhodes, C. J. (2017). The imperative for regenerative agriculture. Science Progress, 100(1), 80-129. https:// doi.org/10.3184/003685017X14876775256165

Rockström, J., Steffen, W., Noone, K., Persson, Å., Chapin, F. S., Lambin, E. F., Lenton, T. M., Scheffer, M., Folke, C., Schellnhuber, H. J., Nykvist, B., de Wit, C. A., Hughes, T., van der Leeuw, S., Rodhe, H., Sörlin, S., Snyder, P. K., Costanza, R., Svedin, U., \& Falkenmark, M. (2009). A safe operating space for humanity. Nature, 461(7263), 472-475. https://doi.org/ 10.1038/461472a

Roe, D., Turner, B., Chausson, A., Seddon, N., \& Hemmerle, E. (2021). Investing in nature for development: Do nature-based interventions deliver local development outcomes? International Institute for Environment and Development. https://pubs.iied.org/ 20206iied

Rosado, L., \& Kalmykova, Y. (2019). Combining industrial symbiosis with sustainable supply chain management for the development of urban communities. IEEE Engineering Management Review, 47(2), 103-114. https://doi.org/10.1109/ EMR.2019.2911060

Samset, I. D., \& Accorigi, A. (2020). Survey report on regulatory obstacles and drivers for boosting a sustainable and circular urban biobased economy. Urban Agenda for the EU Circular Economy. https://futurium.ec.europa.eu/ga/urban-agenda/ circular-economy/library/survey-report-regulatoryobstacles-and-drivers-boosting-sustainable-andcircular-urban-biobased

Santamouris, M. (2014). On the energy impact of urban heat island and global warming on buildings. Energy and Buildings, 82, 100-113. https://doi.org/10.1016/ j.enbuild.2014.07.022

Semidor, C., \& Venit-Gbedji, F. (2009). Outdoor elements providing urban comfort: The role of fountains in the soundscape. In PLEA 2009 26th Conference on Passive and Low Energy Architecture, 22-24 Jun. The Pennsylvania State University.

Shafique, M., Xue, X., \& Luo, X. (2020). An overview of carbon sequestration of green roofs in urban areas. Urban Forestry \& Urban Greening, 47, Article 126515. https://doi.org/10.1016/j.ufug.2019.126515

Sheppard, C., \& Phillips, G. (2015). Bird-friendly building design. American Bird Conservancy. https://www. sfvaudubon.org/wp-content/uploads/2020/08/BirdFriendly-Building-Design_Updated-April-2019.pdf

Shrestha, P., Small, G. E., \& Kay, A. (2020). Quantifying nutrient recovery efficiency and loss from compost-based urban agriculture. PloS One, 15(4), Article e0230996. https://doi.org/10.1371/journal. pone.0230996

Silva, P. W. S., Benites, H. S., Monteiro, L. M., \& Duarte, D. H. S. (2017). Instrumentos urbanísticos para incremento de vegetação em áreas urbanas: Análise comparada a partir da quota ambiental do município de São Paulo: [Planning instruments for vegetation enhancement in urban areas: Compared analysis based on São Paulo's environmental quota]. In B. A. N. Teixeira, É. Masiero, \& C. Pierini (Eds.), SINGEURB 2017, Simpósio nacional de gestão e engenharia urbana, Cidades e objetivos do desenvolvimento sustentável [National symposium of urban management and engineering, Cities and sustainable development goals] (pp. 905-918). Universidade Federal de São Carlos.

Sonter, L. J., Herrera, D., Barrett, D. J., Galford, G. L., Moran, C. J., \& Soares-Filho, B. S. (2017). Mining drives extensive deforestation in the Brazilian Amazon. Nature Communications, 8(1), Article 1013. https://doi.org/10.1038/s41467-017-00557-w

Stahel, R. W. (1982). The product-life factor. In S. G. Orr (Ed.), An inquiry into the nature of sustainable societies: The role of the private sector (pp. 72-104). Houston Area Research Center. https://p2infohouse. org/ref/33/32217.pdf

Steffen, W., Richardson, K., Rockstrom, J., Cornell, S. E., Fetzer, I., Bennett, E. M., Biggs, R., Carpenter, S. R., de Vries, W., de Wit, C. A., Folke, C., Gerten, D., Heinke, J., Mace, G. M., Persson, L. M., Ramanathan, V., Reyers, B., \& Sorlin, S. (2015). Planetary boundaries: Guiding human development on a changing planet. Science, 347(6223), Article 1259855. https:// doi.org/10.1126/science.1259855 
Swinbourne, R., \& Rosenwax, J. (2017). Green infrastructure: A vital step to brilliant Australian cities. AECOM. https://aecom.com/brilliantcityinsights/brilliantcities-insights-greening

Taylor Buck, N., \& While, A. (2021). The urban bioeconomy: Extracting value from the ecological and biophysical. Journal of Environmental Planning and Management, 64(2), 182-201. https://doi.org/10.1080/ 09640568.2020 .1763931

Theodorou, P., Radzevičiūtè, R., Lentendu, G., Kahnt, B., Husemann, M., Bleidorn, C., Settele, J., Schweiger, O., Grosse, I., Wubet, T., Murray, T. E., \& Paxton, R. J. (2020). Urban areas as hotspots for bees and pollination but not a panacea for all insects. Nature Communications, 11(1), 1-13. https://doi.org/10.1038/ s41467-020-14496-6

Ugolini, F., Massetti, L., Calaza-Martínez, P., Cariñanos, P., Dobbs, C., Ostoic, S. K., Marin, A. M., Pearlmutter, D., Saaroni, H., Šaulienè, I., Simoneti, M., Verlič, A., Vuletić, D., \& Sanesi, G. (2020). Effects of the Covid-19 pandemic on the use and perceptions of urban green space: An international exploratory study. Urban Forestry \& Urban Greening, 56, Article 126888. https://doi.org/10.1016/j.ufug. 2020.126888

United Nations. (2019). Decade on ecosystem restoration (2021-2030) (A/RES/73/284).

van den Bosch, M., \& Ode Sang, Å. (2017). Urban natural environments as nature-based solutions for improved public health-A systematic review of reviews. Environmental Research, 158, 373-384. https://doi.org/10.1016/j.envres.2017.05.040

Vincent, J. F. V., Bogatyreva, O. A., Bogatyrev, N. R., Bowyer, A., \& Pahl, A.-K. (2006). Biomimetics: Its practice and theory. Journal of the Royal Society, Interface, 3(9), 471-482. https://doi.org/10.1098/ rsif.2006.0127

Volans. (2020). Procuring a regenerative economy: The critical role of sourcing in generating the future we want. https://volans.com/wp-content/uploads/ 2020/01/Procuring-a-Regenerative-EconomyFINAL.pdf

WHO Regional Office for Europe. (2016). Urban green spaces and health-A review of evidence. https:// www.euro.who.int/en/health-topics/environmentand-health/urban-health/publications/2016/urbangreen-spaces-and-health-a-review-of-evidence2016

Wielemaker, R., Stuiver, J., Zeeman, G., \& Weijma, J. (2020). Identifying Amsterdam's nutrient hotspots: A new method to map human excreta at building and neighborhood scale. Journal of Industrial Ecology, 24(3), 473-484. https://doi.org/10.1111/jiec.12962

Wild, T., Freitas, T., \& Vandewoestijne, S. (Eds.). (2020). Nature-based solutions: State of the art in EU-funded projects, Publications Office of the European Union.

Wong, T. H. F., \& Brown, R. R. (2009). The water sensitive city: Principles for practice. Water Science and Technology, 60(3), 673-682. https://doi.org/ 10.2166/wst.2009.436

World Economic Forum. (2020). The future of nature and business (New Nature Economy report II). http://www3.weforum.org/docs/WEF_The_Future_ Of_Nature_And_Business_2020.pdf

Yang, H.-S., Kang, J., \& Cheal, C. (2013). Randomincidence absorption and scattering coefficients of vegetation. Acta Acustica United with Acustica, 99(3), 379-388. https://doi.org/10.3813/AAA.918619

Zhu-Barker, X., Bailey, S. K., Paw U, K. T., Burger, M., \& Horwath, W. R. (2017). Greenhouse gas emissions from green waste composting windrow. Waste Management, 59, 70-79. https://doi.org/10.1016/ j.wasman.2016.10.004

Zimmann, R., O’Brien, H., Hargrave, J., \& Morrell, M. (2016). The circular economy in the built environment. ARUP. https://www.arup.com/perspectives/ publications/research/section/circular-economy-inthe-built-environment

\section{About the Authors}
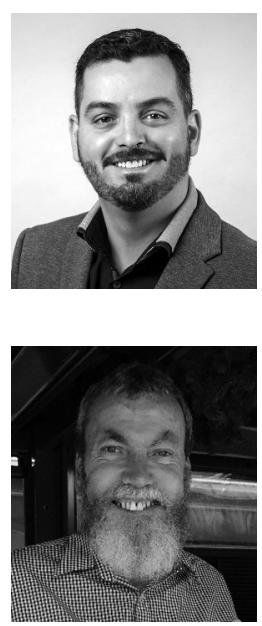

Henrique Sala Benites is a PhD candidate in the UNSW School of Built Environment with over 15 years of experience in architectural science, sustainability, and certifications as LEED and AQUA-HQE. As an architect and urbanist, he holds a master's degree in bioclimatic architecture and a postgraduate degree in urban engineering. Besides being an Ellen MacArthur Foundation's Circular Economy Pioneer, he engages in different initiatives of climate change, nature-based solutions, urban sustainability, and circular economy, including the development of international standards.

Paul Osmond is associate professor in the UNSW School of Built Environment, which he joined in 2010 following several years as the university's environment manager. Previously, he worked in environmental management, landscape, and urban design. Paul has qualifications in applied science, environmental management, and landscape design. He is a certified environmental practitioner, registered environmental auditor, Green Star accredited professional, and Fitwel "ambassador." His publications include 34 journal articles, 45 refereed conference papers, nine book chapters, and one book. 